\section{SciDioc \\ Evaluation of Postoperative Complications after Mandibular Third Molar Extraction without Suture and its Association with Age and Gender \\ International Journal of Dentistry and Oral Science (IJDOS) ISSN: 2377-8075}

Research Article

Keerthana Balaji ${ }^{1}$, Pradeep $\mathrm{D}^{2 *}$

${ }^{1}$ Saveetha Dental College and Hospitals, Saveetha Institute of Medical and Technical Sciences, Saveetha University, Chennai 600077, Tamil Nadu, India. ${ }^{2}$ Associate Professor, Department of Oral and Maxillofacial Surgery, Saveetha Institute of Medical and Technical Sciences, Saveetha University, Chennai 600077, Tamil Nadu, India.

\title{
Abstract
}

Extraction of impacted teeth is one of the most common operations in oral and maxillofacial surgery. Assessment of the effectiveness of sutureless closure of wounds on postoperative complications after extraction of mandibular third molars. This is a Retrospective study conducted in the university setting. This study included patients who reported to private dental hospital for the removal of mandibular third molars. Inclusion criteria of this study included patients who required removal of mandibular third molars and exclusion criteria included patients with drug allergies and patients who are pregnant or currently lactating. Data was collected and tabulated in excel. Data was analysed using IBM SPSS Statistical Analyzer(23.0 version) Frequency distribution and descriptive analysis were carried out. The association between the variables was analysed and assessed using Pearson Chi-square test. P value $<0.05$ was considered to be statistically significant. Patients experienced less postoperative complications in wound closure without suture compared to wound closure with suture. Secondary closure has significant advantage over primary closure based on postoperative pain and swelling.

Keywords: Post Operative Pain; Mandibular Third Molars; Primary Closure; Secondary Closure.

\section{Introduction}

Extraction of impacted teeth is one of the most common operations in oral and maxillofacial surgery. Postoperative pain and swelling are the most common complications [2]. The other postoperative complications include Trismus, Alveolar Osteitis, Extended Hemorrhage. The severity of these symptoms is dependent on multiple factors such as the operative time, the difficulty of the procedure, the extent of the ostectomy, the oral hygiene status of the patient and the competence of the surgeon[5]. Post operative pain and swelling are mainly due to inflammatory processes initiated by surgical trauma. Damage to the capillary vessels and the release of inflammatory cytokines as a result of trauma lead to increased permeability of vessels which results in accumulation of sero-sanguinous fluid and exudate $[25,24,39]$. Post operative complications can be a burden for both patients and surgeons and may result in a loss of productivity because at least $45 \%$ of patients require multiple visits to the surgeon. It can also be costly in terms of the clinic time required to manage the patient's symp- toms. Many individuals rate the pain of tooth extraction as very severe or intolerable. The pain of tooth extraction varies among individuals depending upon their anxiety level and each extraction of an individual may be quite different [24, 53]. Post-operative healing can be primary healing or secondary healing [14]. Primary healing or primary closure is the complete reapposition of the third molar flaps post surgery using suturing.Postoperative healing in extraction with sutures depend on the flap design used.This is healing by primary intention $[6,35]$. In secondary intention the socket remains in communication with the oral cavity [38]. This is healing by secondary intention. Secondary closure of the wound aids in drainage of fluid from the socket thereby reducing postoperative pain and swelling. This is mostly employed in excision of salivary gland and salivary duct swelling such as ranula [10,29]. The main purpose of suture in primary closure is to provide an intimate contact of gingival tissue around second molar, control of haemorrhage, to avoid food lodgement, wound dehiscence and to prevent infection of socket. All suture materials produce tissue response which varies according to the anatomical site in

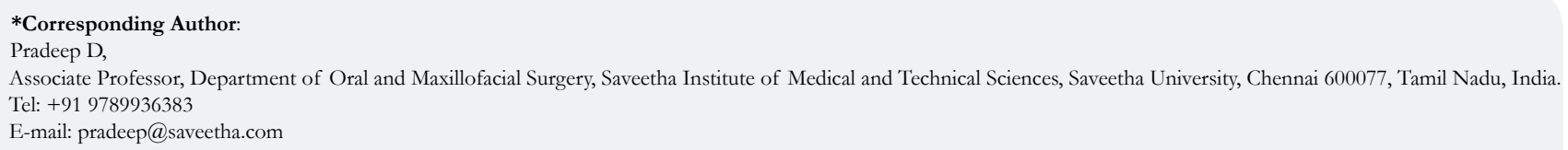

Citation: Keerthana Balaji, Pradeep D. Evaluation of Postoperative Complications after Mandibular Third Molar Extraction without Suture and its Association with Age and Gender Int J Dentistry Oral Sci. 2021;8(8):3832-3838. doi: http://dx.doi.org/10.19070/2377-8075-21000785

Copyright: Pradeep $\mathbf{D}^{\circ}$ 2021. This is an open-access article distributed under the terms of the Creative Commons Attribution License, which permits unrestricted use, distribution and reproduction in any medium, provided the original author and source are credited. 
which they are used ranging from extractions to trauma and osteotomies $[15,8,1,18]$. Sometimes, Suturing may also create a oneway valve that allows for debris to enter the socket but not easily escape which will further cause infection $[50,26]$.

Previously our team has a rich experience in working on various research projects across multiple disciplines. (Jain, 2017 [18]); (Varghese, Ramesh and Veeraiyan, 2019 [54]); (Ashok and Ganapathy, 2019 [3]); (Padavala and Sukumaran, 2018 [30]); (Ke et al., 2019 [21]); (Ezhilarasan, 2018 [11]); (Krishnan et al., 2018 [22]); (Ezhilarasan, Sokal and Najimi, 2018 [13); (Pandian, Krishnan and Kumar, 2018 [32]); (Ramamurthy and Mg, 2018 [42]); (Gupta, Ariga and Deogade, 2018 [16]); (Vikram et al., 2017 [57]); (Paramasivam, Vijayashree Priyadharsini and Raghunandhakumar, 2020 [33]); (Palati et al., 2020 [31]); (Samuel, Acharya and Rao, 2020 [48]). Now the growing trend in this area motivated us to pursue this project.

The aim of the study was to compare the effect of Suture less closure of the surgical wound after removal of mandibular third molar on post-operative pain, swelling, extended haemorrhage and dry socket to closure with sutures.

\section{Materials And Methods}

This retrospective study was conducted in the university setting. Data chosen for evaluation were patients who reported to a private dental college for the removal of mandibular third molars. The details of the patients were obtained from analysis of 86,000 patients from June 2019 to March 2020 from patient dental records. The study was conducted after getting ethical approval from the Institutional Ethical Committee (Ethical approval number : SDC/SIHEC/2020/DIASDATA/0619-0320).Cross verification was done with the help of patient dental records data. To minimise sampling bias all data were included. The inclusion criteria included patients who required removal of impacted mandibular third molars, prophylactic removal of mandibular third molars and patients with acute pericoronitis. The exclusion criteria included patients with drug allergies and patients who are pregnant or currently lactating. A total records of 296 records which satisfied the inclusion and exclusion criteria were included in the study. The age range of patients included for this study was 18-80 years.From the preoperative and postoperative records of the study population, data such as age, gender, postoperative findings and observations were obtained. Data was downloaded from the patient dental records and imported to Excel. Data which was not required were excluded. Data was analysed using IBM SPSS Statistical Analyzer (23.0 version). Frequency distribution and descriptive analysis were carried out. The correlation and association between the variables were analysed and assessed using Pearson Chi-square test.p value less than 0.05 was considered to be statistically significant.Results were obtained in the form of graphs.

\section{Results \& Discussion}

The study included 296 participants who underwent extraction of mandibular third molars. In regard to age, majority of the study population that is $37.5 \%$ and $40.2 \%$ of patients belonging to the

Figure 1: This bar graph represents the association between age and pain in the extraction socket post mandibular third extraction. $\mathrm{X}$ axis represents the age and $\mathrm{Y}$-axis represents the number of patients who underwent mandibular third molar extraction. Pearson Chi square test was done, $\mathrm{p}$ value $=0.000<0.05$ hence the association is statistically significant proving that age influences pain in the extraction socket post mandibular third molar extraction.

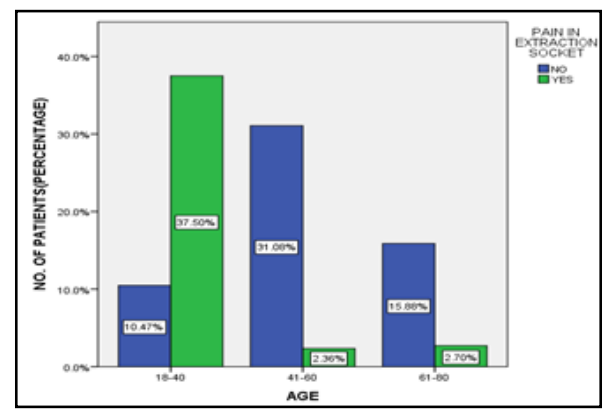

Figure 2: This bar graph represents the association between age and postoperative swelling in mandibular third molar extraction. $\mathrm{X}$ - axis represents the age and $\mathrm{Y}$-axis represents the number of patients who underwent mandibular third molar extraction. Pearson Chi square test was done, $\mathrm{p}$ value $=\mathbf{0 . 0 0 0}<0.05$ hence the association is statistically significant proving that age influences postoperative swelling in extraction of mandibular third molars.

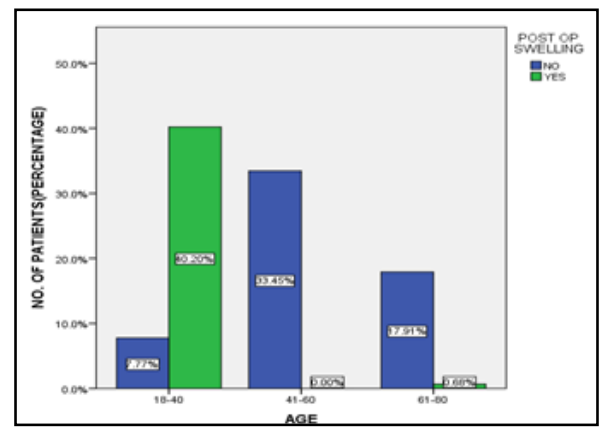


Figure 3: This bar graph represents the association between age and extended hemorrhage post mandibular third extraction. $\mathrm{X}$ - axis represents the age and $\mathrm{Y}$-axis represents the number of patients who underwent mandibular third molar extraction. Pearson Chi square test was done, $\mathrm{p}$ value $=0.000<0.05$ hence the association is statistically significant proving that age influences extended hemorrhage post mandibular third molar extraction.

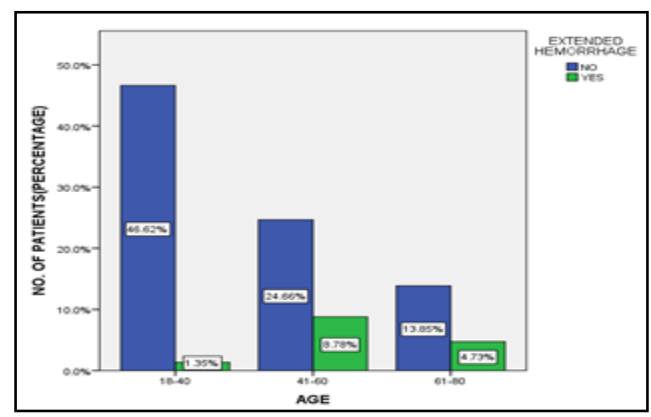

Figure 4: This bar graph represents the association between age and alveolar osteitis post mandibular third extraction. X- axis represents the age and $\mathrm{Y}$-axis represents the number of patients who underwent mandibular third molar extraction. Pearson Chi square test was done, $\mathrm{p}$ value $=0.002<0.05$ hence the association is statistically significant proving that age influences alveolar osteitis post mandibular third molar extraction.

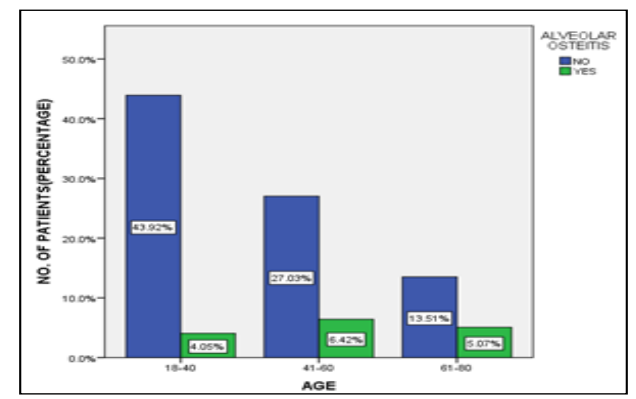

Figure 5: This bar graph represents the association between gender and pain in the extraction socket post mandibular third extraction. $\mathrm{X}$ - axis represents the gender and $\mathrm{Y}$-axis represents the number of patients who underwent mandibular third molar extraction. Pearson Chi square test was done, $p$ value $=0.734>0.05$ hence the association is not statistically significant proving that gender does not influence pain in the extraction socket post mandibular third molar extraction.

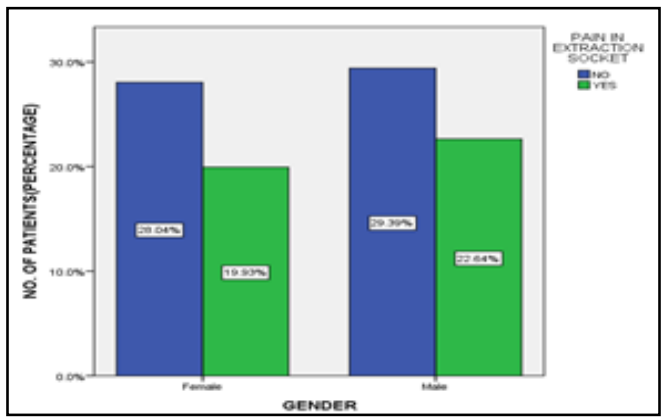

Figure 6: This bar graph represents the association between gender and postoperative swelling in mandibular third extraction. $\mathrm{X}$ - axis represents the age and Y-axis represents the number of patients who underwent mandibular third molar extraction. Pearson Chi square test was done, $\mathrm{p}$ value $=\mathbf{0 . 6 2 8}>0.05$ hence the association is not statistically significant proving that gender does not influence postoperative swelling in extraction of mandibular third molar.

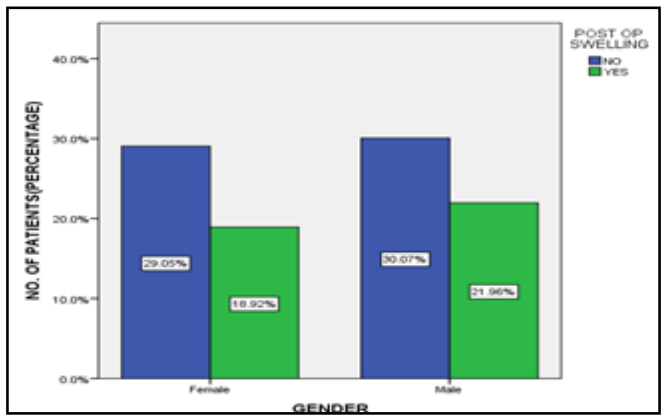


Figure 7: This bar graph represents the association between gender and extended hemorrhage post mandibular third extraction. $\mathrm{X}$ - axis represents the gender and Y-axis represents the number of patients who underwent mandibular third molar extraction. Pearson Chi square test was done, $\mathrm{p}$ value $=\mathbf{0 . 9 7 2}>0.05$ hence the association is not statistically significant proving that gender does not influence extended hemorrhage post mandibular third molar extraction.

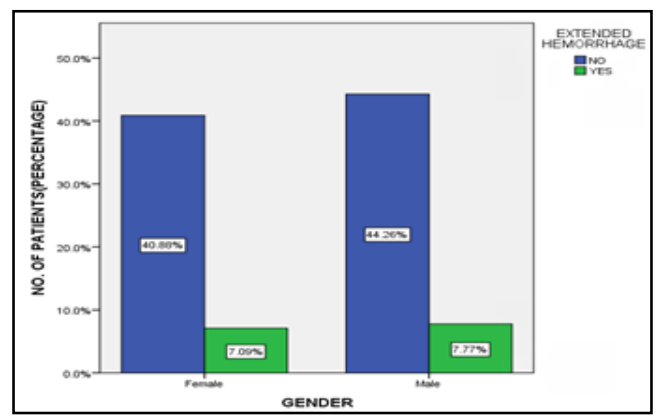

Figure 8: This bar graph represents the association between gender and alveolar osteitis post mandibular third extraction. X- axis represents the gender and Y-axis represents the number of patients who underwent mandibular third molar extraction. Pearson Chi square test was done, $\mathrm{p}$ value $=0.535>0.05$ hence the association is not statistically significant proving that gender does not influence alveolar osteitis post mandibular third molar extraction.

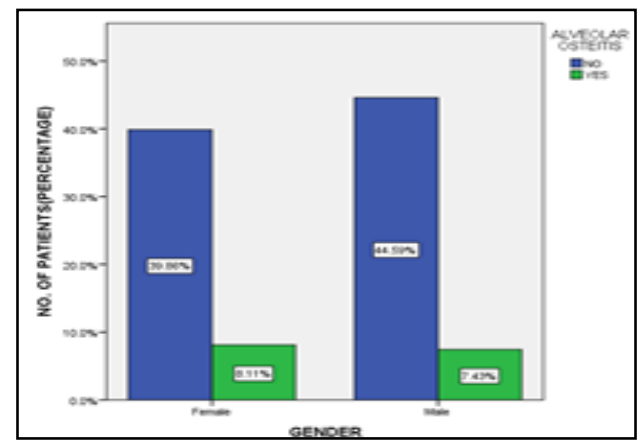

Figure 9: This bar graph represents the association between type of wound closure and pain in the extraction socket post mandibular third extraction. $\mathrm{X}$ - axis represents the type of wound closure and Y-axis represents the number of patients who underwent mandibular third molar extraction.Pearson Chi square test was done, $\mathrm{p}$ value $=0.000<0.05$ hence the association is statistically significant proving that type of wound closure influences pain in the extraction socket post mandibular third molar extraction.

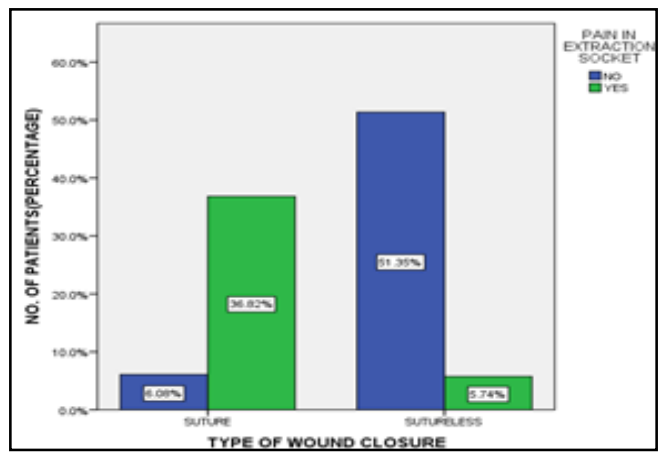

Figure 10: This bar graph represents the association between type of wound closure and postoperative pain in mandibular third extraction.X-axis represents the type of wound closure and Y-axis represents the number of patients who underwent mandibular third molar extraction. Pearson Chi square test was done, $p$ value $=0.000<0.05$ hence the association is statistically significant proving that type of wound closure influences postoperative swelling in mandibular third molar extraction.

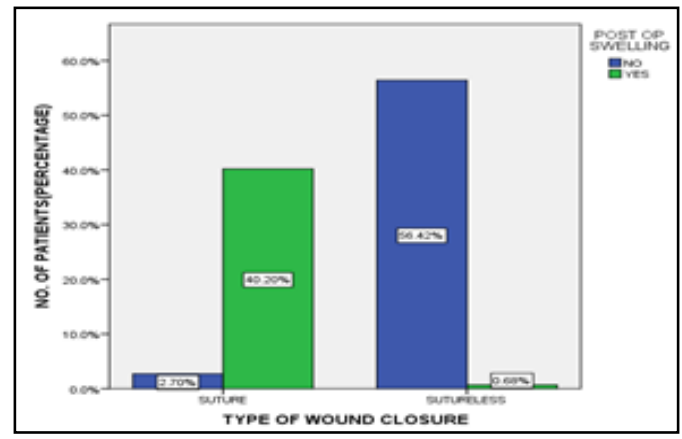


Figure 11: This bar graph represents the association between type of wound closure and extended hemorrhage post mandibular third extraction.X-axis represents the type of wound closure and $\mathrm{Y}$-axis represents the number of patients who underwent mandibular third molar extraction. Pearson Chi square test was done, $\mathrm{p}$ value $=0.000<0.05$ hence the association is statistically significant proving that type of wound closure influences extended hemorrhage post mandibular third molar extraction.

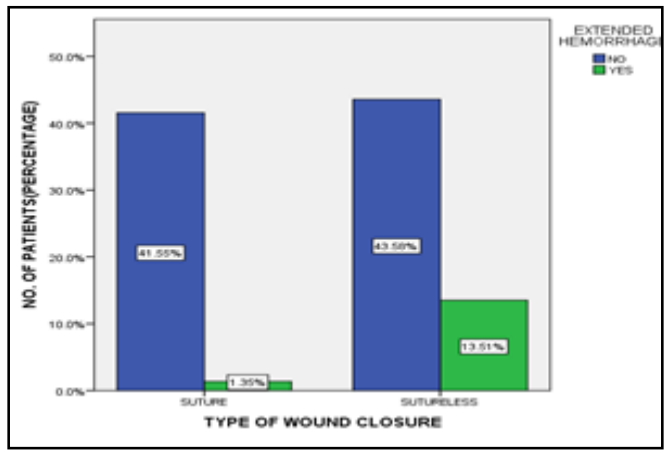

Figure 12: This bar graph represents the association between type of wound closure and pain in the extraction socket post mandibular third extraction. $\mathrm{X}$ - axis represents the type of wound closure and $\mathrm{Y}$-axis represents the number of patients who underwent mandibular third molar extraction.Pearson Chi square test was done, $\mathrm{p}$ value $=0.002<0.05$ hence the association is statistically significant proving that type of wound closure influences alveolar osteitis post mandibular third molar extraction.

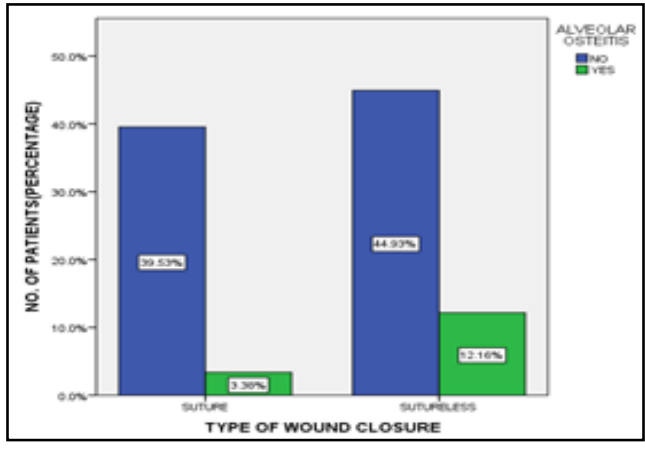

age group 18-40 years showed higher incidence of postoperative pain and swelling(Figure-1\&2) whereas $8.78 \%$ and $6.42 \%$ of patients belonging to age group 41-60 years showed higher incidence of extended hemorrhage and alveolar osteitis after extraction of mandibular third molar(Figure-3\&4). Considering gender, $22.64 \%$ of males and $19.93 \%$ of females experienced postoperative pain(Figure-5). Similarly, $18.92 \%$ of females and $21.96 \%$ of males were observed to have postoperative swelling after mandibular third molar extraction(Figure-6).About $7.09 \%$ of females and $7.77 \%$ of males were observed with extended hemorrhage after extraction(Figure-7). Among the study population, $8.11 \%$ of females and $7.43 \%$ of males had alveolar osteitis(Figure- 8 ). In terms of type of wound closure, $36.82 \%$ of patients experienced postoperative pain on primary closure while only $5.74 \%$ of patients experienced postoperative pain on secondary closure(Figure-9). About $40.20 \%$ of patients were observed with postoperative swelling after extraction with sutures while only $0.68 \%$ of patients had swelling after extraction without sutures(Figure-10).On the contrary, $13.51 \%$ of patients were observed with extended hemorrhage in secondary closure while only $1.35 \%$ of patients were observed with extended hemorrhage in primary closure (Figure-11).Similarly, $12.16 \%$ of patients had alveolar osteitis in extraction without sutures while only $3.38 \%$ of patients had alveolar osteitis incase of healing with sutures(Figure-12).

Results of this study showed that the main indicators that is postoperative pain and swelling is higher in case of wound closure with sutures when compared to wound closure without suture. Whereas haemorrhage and alveolar osteitis were observed to be slightly higher in sutureless wound closure which can be attrib- uted towards inadequate irrigation of extraction socket, remnants of debris/ bone fragments in the socket, patient's smoking habit, oral hygiene practices and systemic disorders. Application of $0.2 \%$ chlorhexidine-based gel applied to the alveolar socket once after extraction and prescribing prophylactic antibiotic courses in patients with systemic conditions prevent the occurrence of alveolar osteitis $[20,49,44]$.

This result is in agreement with many of those reported in the literature. Brabander and cattaneo evaluated two different types of wound closure after removing third molars and concluded that secondary closure was found to be preferable as it reduces pain and swelling post surgery[4]. Pasqualini et al obtained results that indicated that secondary closure of the socket causes less inconvenience for the patients as it appears to minimise post extraction swelling and pain [34]. In a split mouth study on 56 patients conducted by Dubois et al showed that secondary closure was found to minimise swelling and pain in the immediate postoperative period, helping to reduce patient discomfort [9]. Holland and Hindle showed that post operative pain and swelling markedly less in secondary closure compared to primary closure [17]. In contrast, Suddhasthira et al reported no differences according to the type of wound healing [52]. Rakprasitkul and pairuch vej observed no statistically significant differences in pain and swelling between two groups of patients who underwent primary closure and secondary closure [40]. Some authors suggested primary closure of the flap, but keeping a drain in place during 72 hours while the technique has no impact upon post operative pain, it has been proven to reduce post operative swelling [46]. Therefore, dentists should have sound knowledge regarding sutureless technique in 
mandibular third molar extraction and its effect on postoperative healing [36, 28].

Our institution is passionate about high quality evidence based research and has excelled in various fields. (Pc, Marimuthu and Devadoss, 2018 [37]; Ramesh et al., 2018 [43]; Vijayashree Priyadharsini, Smiline Girija and Paramasivam, 2018 [56]; Ezhilarasan, Apoorva and Ashok Vardhan, 2019 [12]; Ramadurai et al., 2019 [41]; Sridharan et al., 2019 [51]; Vijayashree Priyadharsini, 2019 [55]; Chandrasekar et al., 2020 [7]; Mathew et al., 2020 [27]; R et al., 2020 [45]; Samuel, 2021 [47]). We hope this study adds to this rich legacy.

\section{Conclusion}

Within the limitations of this study, it can be concluded that postoperative pain and swelling were observed to be more in patients who underwent extraction of mandibular third molars with sutures compared to patients who underwent extractions without sutures. Experience of pain and postoperative swelling was found to be higher in the age group 18-40 years. Therefore, Secondary closure has significant advantages over primary closure in terms of postoperative pain, swelling and patients comfort.However, due to small sample size, multicentre studies with large study population are needed to be conducted for further analysation

\section{References}

[1]. Abhinav RP, Selvarasu K, Maheswari GU, Taltia AA. The Patterns and Etiology of Maxillofacial Trauma in South India. Ann Maxillofac Surg. 2019 Jan-Jun;9(1):114-117. Pubmed PMID: 31293938

[2]. Alexander RE. Dental extraction wound management: a case against medicating postextraction sockets. J Oral Maxillofac Surg. 2000 May;58(5):53851. Pubmed PMID: 10800910.

[3]. Ashok V, Ganapathy D. A geometrical method to classify face forms. J Oral Biol Craniofac Res. 2019 Jul-Sep;9(3):232-235. Pubmed PMID: 31198677.

[4]. de Brabander EC, Cattaneo G. The effect of surgical drain together with a secondary closure technique on postoperative trismus, swelling and pain after mandibular third molar surgery. Int J Oral Maxillofac Surg. 1988 Apr;17(2):119-21. Pubmed PMID: 3133420.

[5]. Brekke JH, Bresner M, Reitman MJ. Effect of surgical trauma and polylactate cubes and granules on the incidence of alveolar osteitis in mandibular third molar extraction wounds. J Can Dent Assoc. 1986 Apr;52(4):315-9. Pubmed PMID: 3518884.

[6]. Capuzzi P, Montebugnoli L, Vaccaro MA. Extraction of impacted third molars. A longitudinal prospective study on factors that affect postoperative recovery. Oral Surg Oral Med Oral Pathol. 1994 Apr;77(4):341-3. Pubmed PMID: 8015796.

[7]. Chandrasekar R, Chandrasekhar S, Sundari KKS, Ravi P. Development and validation of a formula for objective assessment of cervical vertebral bone age. Prog Orthod. 2020 Oct 12;21(1):38. Pubmed PMID: 33043408.

[8]. Christabel A, Anantanarayanan P, Subash P, Soh CL, Ramanathan M, Muthusekhar MR, Narayanan V. Comparison of pterygomaxillary dysjunction with tuberosity separation in isolated Le Fort I osteotomies: a prospective, multi-centre, triple-blind, randomized controlled trial. Int J Oral Maxillofac Surg. 2016 Feb;45(2):180-5. Pubmed PMID: 26338075.

[9]. Dubois DD, Pizer ME, Chinnis RJ. Comparison of primary and secondary closure techniques after removal of impacted mandibular third molars. J Oral Maxillofac Surg. 1982 Oct;40(10):631-4. Pubmed PMID: 6956684.

[10]. Evans AW, Aghabeigi B, Leeson RM, O'Sullivan C, Eliahoo J. Assessment of surgeon competency to remove mandibular third molar teeth. Int J Oral Maxillofac Surg. 2002 Aug;31(4):434-8. Pubmed PMID: 12361080.

[11]. Ezhilarasan D. Oxidative stress is bane in chronic liver diseases: Clinical and experimental perspective. Arab J Gastroenterol. 2018 Jun;19(2):56-64. PMID: 29853428.

[12]. Ezhilarasan D, Apoorva VS, Ashok Vardhan N. Syzygium cumini extract induced reactive oxygen species-mediated apoptosis in human oral squamous carcinoma cells. J Oral Pathol Med. 2019 Feb;48(2):115-121. Pubmed PMID: 30451321.

[13]. Ezhilarasan D, Sokal E, Najimi M. Hepatic fibrosis: It is time to go with hepatic stellate cell-specific therapeutic targets. Hepatobiliary Pancreat Dis Int. 2018 Jun;17(3):192-197. Pubmed PMID: 29709350.

[14]. Garcia Garcia A, Gude Sampedro F, Gandara Rey J, Gallas Torreira M. Trismus and pain after removal of impacted lower third molars. J Oral Maxillofac Surg. 1997 Nov;55(11):1223-6. Pubmed PMID: 9371111.

[15]. Goldberg MH, Nemarich AN, Marco WP 2nd. Complications after mandibular third molar surgery: a statistical analysis of 500 consecutive procedures in private practice. J Am Dent Assoc. 1985 Aug;111(2):277-9. Pubmed PMID: 3862695.

[16]. Gupta P, Ariga P, Deogade SC. Effect of Monopoly-coating Agent on the Surface Roughness of a Tissue Conditioner Subjected to Cleansing and Disinfection: A Contact Profilometric In vitro Study. Contemp Clin Dent. 2018 Jun;9(Suppl 1):S122-S126. Pubmed PMID: 29962776.

[17]. Holland CS, Hindle MO. The influence of closure or dressing of third molar sockets on post-operative swelling and pain. Br J Oral Maxillofac Surg. 1984 Feb;22(1):65-71. Pubmed PMID: 6582934.

[18]. Jain AR. Prevalence of partial edentulousness and treatment needs in rural population of South India. World J Dentistry. 2017 Jun;8(3):213-7.

[19]. Vijayakumar Jain S, Muthusekhar MR, Baig MF, Senthilnathan P, Loganathan S, Abdul Wahab PU, Madhulakshmi M, Vohra Y. Evaluation of ThreeDimensional Changes in Pharyngeal Airway Following Isolated Lefort One Osteotomy for the Correction of Vertical Maxillary Excess: A Prospective Study. J Maxillofac Oral Surg. 2019 Mar;18(1):139-146. Pubmed PMID: 30728705.

[20]. Jesudasan JS, Wahab PU, Sekhar MR. Effectiveness of $0.2 \%$ chlorhexidine gel and a eugenol-based paste on postoperative alveolar osteitis in patients having third molars extracted: a randomised controlled clinical trial. $\mathrm{Br} \mathrm{J}$ Oral Maxillofac Surg. 2015 Nov;53(9):826-30. Pubmed PMID: 26188932.

[21]. Ke Y, Al Aboody MS, Alturaiki W, Alsagaby SA, Alfaiz FA, Veeraraghavan VP, Mickymaray S. Photosynthesized gold nanoparticles from Catharanthus roseus induces caspase-mediated apoptosis in cervical cancer cells (HeLa). Artif Cells Nanomed Biotechnol. 2019 Dec;47(1):1938-1946. Pubmed PMID: 31099261

[22]. Krishnan RP, Ramani P, Sherlin HJ, Sukumaran G, Ramasubramanian A, Jayaraj G, Don KR, Santhanam A. Surgical Specimen Handover from Operation Theater to Laboratory: A Survey. Ann Maxillofac Surg. 2018 JulDec;8(2):234-238. Pubmed PMID: 30693238.

[23]. MP SK. Relationship between dental anxiety and pain experience during dental extractions. Asian J Pharm Clin Res. 2017 Mar 1:458-61.

[24]. Kumar S. The emerging role of botulinum toxin in the treatment of orofacial disorders: Literature update. Asian Journal of Pharmaceutical and Clinical Research. 2017;10(9):21.

[25]. Lopes V, Mumenya R, Feinmann C, Harris M. Third molar surgery: an audit of the indications for surgery, post-operative complaints and patient satisfaction. Br J Oral Maxillofac Surg. 1995 Feb;33(1):33-5. Pubmed PMID: 7718526.

[26]. Marimuthu M, Andiappan M, Wahab A, Muthusekhar MR, Balakrishnan A, Shanmugam S. Canonical Wnt pathway gene expression and their clinical correlation in oral squamous cell carcinoma. Indian J Dent Res. 2018 MayJun;29(3):291-297. Pubmed PMID: 29900911.

[27]. Mathew MG, Samuel SR, Soni AJ, Roopa KB. Evaluation of adhesion of Streptococcus mutans, plaque accumulation on zirconia and stainless steel crowns, and surrounding gingival inflammation in primary molars: randomized controlled trial. Clin Oral Investig. 2020 Sep;24(9):3275-3280. Pubmed PMID: 31955271.

[28]. Mp S K, Rahman R. Knowledge, awareness, and practices regarding biomedical waste management among undergraduate dental students. Asian J Pharm Clin Res. 2017;10(8):341-345.

[29]. Packiri S, Gurunathan D, Selvarasu K. Management of Paediatric Oral Ranula: A Systematic Review. J Clin Diagn Res. 2017 Sep;11(9):ZE06-ZE09. Pubmed PMID: 29207849.

[30]. Padavala S, Sukumaran G. Molar Incisor Hypomineralization and Its Prevalence. Contemp Clin Dent. 2018 Sep;9(Suppl 2):S246-S250. Pubmed PMID: 30294152

[31]. Palati S, Ramani P, Shrelin HJ, Sukumaran G, Ramasubramanian A, Don KR, Jayaraj G, Santhanam A. Knowledge, Attitude and practice survey on the perspective of oral lesions and dental health in geriatric patients residing in old age homes. Indian J Dent Res. 2020 Jan-Feb;31(1):22-25. Pubmed PMID: 32246676.

[32]. Pandian KS, Krishnan S, Kumar SA. Angular photogrammetric analysis of the soft-tissue facial profile of Indian adults. Indian J Dent Res. $2018 \mathrm{Mar}-$ Apr;29(2):137-143. Pubmed PMID: 29652003.

[33]. Paramasivam A, Vijayashree Priyadharsini J, Raghunandhakumar S. N6adenosine methylation $(\mathrm{m} 6 \mathrm{~A})$ : a promising new molecular target in hypertension and cardiovascular diseases. Hypertens Res. 2020 Feb;43(2):153154. Pubmed PMID: 31578458.

[34]. Pasqualini D, Cocero N, Castella A, Mela L, Bracco P. Primary and second- 
ary closure of the surgical wound after removal of impacted mandibular third molars: a comparative study. Int J Oral Maxillofac Surg. 2005 Jan;34(1):527. Pubmed PMID: 15617967.

[35]. Patil SB, Durairaj D, Suresh Kumar G, Karthikeyan D, Pradeep D. Comparison of Extended Nasolabial Flap Versus Buccal Fat Pad Graft in the Surgical Management of Oral Submucous Fibrosis: A Prospective Pilot Study. J Maxillofac Oral Surg. 2017 Sep;16(3):312-321. Pubmed PMID: 28717289.

[36]. Patturaja K, Pradeep D. Awareness of Basic Dental Procedure among General Population. Res J Pharm Technol. 2016;9(9):1349-51.

[37]. J PC, Marimuthu T, C K, Devadoss P, Kumar SM. Prevalence and measurement of anterior loop of the mandibular canal using CBCT: A cross sectional study. Clin Implant Dent Relat Res. 2018 Aug;20(4):531-534. Pubmed PMID: 29624863.

[38]. Peñarrocha M, Sanchis JM, Sáez U, Gay C, Bagán JV. Oral hygiene and postoperative pain after mandibular third molar surgery. Oral Surg Oral Med Oral Pathol Oral Radiol Endod. 2001 Sep;92(3):260-4. Pubmed PMID: 11552141.

[39]. Rahman, R. and Mp, S. K. (2017) 'KNOWLEDGE, ATTITUDE, AND AWARENESS OF DENTAL UNDERGRADUATE STUDENTS REGARDING HUMAN IMMUNODEFICIENCY VIRUS/ACQUIRED IMMUNODEFICIENCY SYNDROME PATIENTS', Asian J Pharm Clin Res, 10(5), pp. 175-180.

[40]. Rakprasitkul S, Pairuchvej V. Mandibular third molar surgery with primary closure and tube drain. Int J Oral Maxillofac Surg. 1997 Jun;26(3):187-90. Pubmed PMID: 9180228.

[41]. Ramadurai N, Gurunathan D, Samuel AV, Subramanian E, Rodrigues SJL. Effectiveness of $2 \%$ Articaine as an anesthetic agent in children: randomized controlled trial. Clin Oral Investig. 2019 Sep;23(9):3543-3550. Pubmed PMID: 30552590.

[42]. Ramamurthy JA, Mg V. Comparison of effect of Hiora mouthwash versus Chlorhexidine mouthwash in gingivitis patients: A clinical trial. Asian J Pharm Clin Res. 2018 Jul 7;11(7):84-8.

[43]. Ramesh A, Varghese S, Jayakumar ND, Malaiappan S. Comparative estimation of sulfiredoxin levels between chronic periodontitis and healthy patients - A case-control study. J Periodontol. 2018 Oct;89(10):1241-1248. Pubmed PMID: 30044495.

[44]. Rao TD, Kumar MP. Analgesic efficacy of paracetamol vs ketorolac after dental extractions. Res J Pharm Technol. 2018;11(8):3375-9.

[45]. R H, Ramani P, Ramanathan A, R JM, S G, Ramasubramanian A, K M. CYP2 C9 polymorphism among patients with oral squamous cell carcinoma and its role in altering the metabolism of benzo[a]pyrene. Oral Surg Oral Med Oral Pathol Oral Radiol. 2020 Sep;130(3):306-312. Pubmed PMID: 32773350
[46]. Sağlam AA. Effects of tube drain with primary closure technique on postoperative trismus and swelling after removal of fully impacted mandibular third molars. Quintessence Int. 2003 Feb;34(2):143-7. Pubmed PMID: 12666865.

[47]. Samuel SR. Can 5-year-olds sensibly self-report the impact of developmental enamel defects on their quality of life? Int J Paediatr Dent. 2021 Mar;31(2):285-286. Pubmed PMID: 32416620.

[48]. Samuel SR, Acharya S, Rao JC. School Interventions-based Prevention of Early-Childhood Caries among 3-5-year-old children from very low socioeconomic status: Two-year randomized trial. J Public Health Dent. 2020 Jan;80(1):51-60. Pubmed PMID: 31710096.

[49]. Sneha S. Knowledge and awareness regarding antibiotic prophylaxis for infective endocarditis among undergraduate dental students. Asian J Pharm Clin Res. 2016 Oct 1;9(2):154-9.

[50]. Singh N, Kumar M, Singh S, Srivastava AS. Primary Closure Versus Secondary Closure after Third Molar Surgery: A Comparative Evaluation of Post-Operative Sequelae. Available from: http://www.ijcmsr.com/uploads/1/0/2/7/102704056/377.pdf

[51]. Sridharan G, Ramani P, Patankar S, Vijayaraghavan R. Evaluation of salivary metabolomics in oral leukoplakia and oral squamous cell carcinoma. J Oral Pathol Med. 2019 Apr;48(4):299-306. Pubmed PMID: 30714209.

[52]. Suddhasthira T, Chaiwat $S$, Sattapongsda P. The comparison study of primary and secondary closure technique after removal of impacted mandibular third molars. Thai J Oral Maxillofac Surg. 1991;5:67-73.

[53]. Sweta VR, Abhinav RP, Ramesh A. Role of Virtual Reality in Pain Perception of Patients Following the Administration of Local Anesthesia. Ann Maxillofac Surg. 2019 Jan-Jun;9(1):110-113. Pubmed PMID: 31293937.

[54]. Varghese SS, Ramesh A, Veeraiyan DN. Blended Module-Based Teaching in Biostatistics and Research Methodology: A Retrospective Study with Postgraduate Dental Students. J Dent Educ. 2019 Apr;83(4):445-450. Pubmed PMID: 30745352.

[55]. Vijayashree Priyadharsini J. In silico validation of the non-antibiotic drugs acetaminophen and ibuprofen as antibacterial agents against red complex pathogens. J Periodontol. 2019 Dec;90(12):1441-1448. Pubmed PMID: 31257588.

[56]. Vijayashree Priyadharsini J, Smiline Girija AS, Paramasivam A. In silico analysis of virulence genes in an emerging dental pathogen A. baumannii and related species. Arch Oral Biol. 2018 Oct;94:93-98. Pubmed PMID: 30015217.

[57]. Vikram NR, Prabhakar R, Kumar SA, Karthikeyan MK, Saravanan R. Ball Headed Mini Implant. J Clin Diagn Res. 2017 Jan;11(1):ZL02-ZL03. Pubmed PMID: 28274084. 